\title{
A Reconceptualization of Brand Image
}

\author{
J. Lucy Lee ${ }^{1}$, Jeffrey D. James ${ }^{1} \&$ Yu Kyoum Kim ${ }^{1}$ \\ ${ }^{1}$ Department of Sport Management, Florida State University, Tallahassee, United States \\ Correspondence: J. Lucy Lee, Department of Sport Management, Florida State University, Tallahassee, FL 32306, \\ United States. Tel: 1-850-570-4004. E-mail: j110f@my.fsu.edu
}

Received: April 26, 2014

Accepted: May 19, $2014 \quad$ Online Published: June 22, 2014

doi:10.5430/ijba.v5n4p1

URL: http://dx.doi.org/10.5430/ijba.v5n4p1

\begin{abstract}
Brand image forms the basis for making better strategic marketing decisions about targeting specific market segments and positioning a product. The phrase, brand image, however, has been defined and applied in various ways by different researchers. The variations in definition can be confusing with regard to brand image measurement and subsequent assessment of brand equity and brand positioning. A revised definition is proposed - the sum of a customer's perceptions about a brand generated by the interaction of the cognitive, affective, and evaluative processes in a customer's mind - to better reflect the concepts discussed relative to brand image in the literature review, content spanning the 1950 s to the present. The revised definition will benefit researchers and marketers through use of unified terminology and meaning, allowing for efficient planning and implementation of marketing strategies to build brand equity.
\end{abstract}

Keywords: brand image, definition, reconceptualization, brand image management

\section{Introduction}

Peter Drucker, who is widely recognized as the "father" of modern management, states there are two fundamental functions of business: marketing and innovation (Drucker \& Maciariello, 2008). He points out that the aim of marketing is branding, which makes selling superfluous and the brand itself desirable. In other words, it is the strength of the brand that makes it possible to sell certain products without any attempts needed to persuade customers with marketing strategies. In marketing, it is all about branding. As a result, much attention has been paid to the concept of brand equity (Aaker, 1991; Aaker \& Biel, 1993; Keller, 1993; 2001; Simon \& Sullivan, 1993; Shankar, Azar, \& Fuller, 2008; Vázquez, del Rio, \& Iglesias, 2002; Washburn \& Plank, 2001; Yoo \& Donthu, 2001).

Brand equity is defined as customers' perceived added value associated with a particular product that is accrued by a brand beyond the functional or utilitarian value of the product (Aaker, 1991; Ambler, 2003; Biel, 1992; Simon \& Sullivan, 1993; Keller, 1993). Customers are more likely to have loyalty toward that brand, if there is a high level of brand equity. Customers with brand loyalty demonstrate patterns of repeat purchasing of the preferred brand, and they often do not leverage alternatives. They are less vulnerable to price fluctuation, and they willingly pay premium prices. The characteristics of brand-loyal customers make it possible for firms to increase their revenues and to lower marketing expenses because sustaining customers is much more cost-efficient than creating new customers. For these reasons, business executives and managers try to obtain a superior level of brand equity to generate marginal cash flow.

To establish brand equity, marketers seek to establish a brand image. Biel (1992) asserts that brand image is a central driver of brand equity.

Any expectation of the cash flow premium enjoyed by a successful brand ultimately depends upon consumer behavior. And consumer behavior is, at root, driven by perception of a brand (p.7).

One good example of this is Nike's decision to cease its business with Sears when Sears merged with Kmart in 2005. Nike could not stand for its brand image to be related to Kmart's low quality and cheap prices and a sinking-ship image. Nike sought to maintain its premium and top-quality image by providing a swoosh brand on Sears shelves, and to avoid creating conflicting images by associating with Kmart. It was more likely to be a brand-image management decision than a business decision (Ives, 2005). The example reflects the importance of brand image.

Brand image forms the basis for making better strategic marketing decisions about how to target market segments 
and position a product. Managers attempt to seek, select, sustain, and support a positive and unique brand image. Brand image makes it possible to differentiate one's brand from the others. When a concrete brand image is created, brand equity can be addressed (Shank, 2008); brand image is a critical component of brand equity.

Table 1. Definitions of brand image

\begin{tabular}{|c|c|c|}
\hline Classification & Authors & Definitions \\
\hline \multirow{3}{*}{$\begin{array}{l}\text { Blanket } \\
\text { definition }\end{array}$} & Newman, 1975 & $\begin{array}{l}\text { A brand can be viewed as a composite image of everything } \\
\text { people associate with it }\end{array}$ \\
\hline & Herzog, 1963 & $\begin{array}{l}\text { Brand image is the sum total of impressions the consumer } \\
\text { receives from many sources }\end{array}$ \\
\hline & Dichter, 1985 & $\begin{array}{l}\text { Brand image is the configuration of the whole field of the } \\
\text { object, the advertising, and more important, the customer's } \\
\text { disposition and the attitudinal screen through which he } \\
\text { observes. }\end{array}$ \\
\hline \multirow{3}{*}{$\begin{array}{l}\text { Emphasis on } \\
\text { symbolism }\end{array}$} & Pohlman \& Mudd, 1973 & $\begin{array}{l}\text { The purchased item is conceptualized as having two kinds of } \\
\text { value for the owner, one for its concrete functional utility and } \\
\text { the other for its utility as a prestige symbol value (i.e., image) }\end{array}$ \\
\hline & Nöth, 1988 & $\begin{array}{l}\text { Brand image include technical matters, product } \\
\text { characteristics, financial value or social suitability }\end{array}$ \\
\hline & Sommers, 1964 & The meaning that a product has perceived product symbolism \\
\hline \multirow{3}{*}{$\begin{array}{l}\text { Emphasis on } \\
\text { meanings or } \\
\text { messages }\end{array}$} & Levy \& Glick, 1973 & $\begin{array}{l}\text { The concept of brand image aptly sums up the idea that } \\
\text { consumers buy brands not only for their physical attributes } \\
\text { and functions, but also because of the meanings connected } \\
\text { with the brands }\end{array}$ \\
\hline & Swartz, 1983 & $\begin{array}{l}\text { In symbolic consumer, interest lies in investigating the role of } \\
\text { products as "messages" }\end{array}$ \\
\hline & Reynolds \& Gutman, 1984 & $\begin{array}{l}\text { The set of meanings and associations that serve to } \\
\text { differentiate a product or service from its competition }\end{array}$ \\
\hline \multirow{2}{*}{$\begin{array}{l}\text { Emphasis on } \\
\text { personification }\end{array}$} & Hendon \& Williams, 1985 & $\begin{array}{l}\text { Brand personality or brand character involves nothing more } \\
\text { than describing a product as if it were a human being }\end{array}$ \\
\hline & Sirgy, 1985 & $\begin{array}{l}\text { Products are assumed to have personality image, just as } \\
\text { people do }\end{array}$ \\
\hline \multirow{2}{*}{$\begin{array}{l}\text { Emphasis on } \\
\text { cognitive or } \\
\text { psychological } \\
\text { elements }\end{array}$} & Gardner \& Levy, 1955 & $\begin{array}{l}\text { The sets of ideas, feelings and attitudes that consumers have } \\
\text { about brands }\end{array}$ \\
\hline & Martineau, 1957 & $\begin{array}{l}\text { The total set of attitudes, the halo of psychological meanings, } \\
\text { the association of feeling, the indelibly written aesthetic } \\
\text { messages over and above the bare physical qualities }\end{array}$ \\
\hline
\end{tabular}

Note: Adapted from 'In search of brand image: a foundation analysis.' (p.112), by Dobni, D. \& Zinkhan, G. M. (1990), Copyright 1990 by the Association for Consumer Research.

The term brand image has been defined and applied in various ways by different researchers (see Dobni \& Zinkhan, 1990) as shown in Table 1. The multiple definitions and interpretations of brand image results in incongruence. If there is no agreement about the definition of brand image, how can researchers and practitioners better understand the formation of brand equity? Because of the lack of a commonly understood definition, the concept of brand image tends to be ill-defined, and it is sometimes understood in a way that is far from the original intent. Despite the use of the same terminology, the concept of brand image has been applied in many different ways. Alternatively, some authors use different terminology to refer to concepts that can be considered under the umbrella term of "brand image." For example, Aaker (1996) uses the term brand identity to refer to a company's corporate image, which is generally seen as part of the brand image. Keller (2001) conceptualizes brand image with terms such as brand associations, brand performance, brand imagery, consumer judgments, and consumer feelings.

As a result of the different usage of the phrase brand image, there are restrictions on the way the concept can be assessed. The variations in definition result in confusion regarding brand image measurement and subsequently brand equity. Without definitional consensus, the measuring and management of brand image are not possible. If 
brand image can be defined in a consistent way that researchers can use and apply, a measure of brand image could be developed. Moving beyond brand image, marketers would be closer to understanding how to build brand equity.

Another reason we to pursue a consistent definition is to enhance efforts to establish brand position in customers' minds. To be successful in the marketplace, good brand positioning is essential. Brand positioning is "the act of designing a company's [...] image so that it occupies a distinct and valued place in the target customer's mind" (Keller, 2008, p. 38). To position a brand, a brand image should be introduced, elaborated, and fortified; successful brand positioning depends on brand image management (Park, Jaworski, \& Maclnnis, 1986). A well-communicated image establishes a brand's position and insulates the brand from the competition.

To determine the brand image, marketers have to research customer beliefs about their brands. However, if there is no agreement with regard to what constitutes brand image, the positioning will be a house of cards. The aim is to locate the brand on the product category ladder in the customers' minds. Any business that is located on the top rung of the ladder in the target customer's mind will have an advantage (Ries \& Trout, 2000). Firms should differentiate their brands and convey why their brands should be chosen over competitive brands. If a company positions its brand in the right way and in a desired direction to influence what customers believe about a brand, the company's profits can be maximized.

The current research focused on reviewing previous research related to brand image; the definitions of the term brand image were classified, and the differences among them were explored. The objective of this study is to introduce a revised definition of brand image that researchers and practitioners are able to utilize to build brand equity.

\section{Literature Review}

2.1 The Chronological Transition of Brand Image Definitions

Table 2. The chronological transition of brand image definitions

\begin{tabular}{|c|c|c|c|}
\hline Time & ears) & Authors & Definitions \\
\hline \multirow{3}{*}{$1950 \mathrm{~s}$} & 1955 & Gardner \& Levy, 1955 & $\begin{array}{l}\text { The sets of ideas, feelings and attitudes that consumers } \\
\text { have about brands -"the social and psychological nature } \\
\text { of products" }\end{array}$ \\
\hline & 1957 & Martineau, 1957 & Brand image is a symbol of the buyer's personality \\
\hline & 1957 & Newman,1957 & $\begin{array}{l}\text { A brand can be viewed as a composite image of } \\
\text { everything people associate with it }\end{array}$ \\
\hline \multirow{3}{*}{$1960 \mathrm{~s}$} & 1963 & Herzog, 1963 & $\begin{array}{l}\text { Brand image is the sum total of impressions the } \\
\text { consumer receives from many sources }\end{array}$ \\
\hline & 1903 & Sommers, 1964 & $\begin{array}{l}\text { The meaning that a product has perceived product } \\
\text { symbolism -"perceived product symbolism" }\end{array}$ \\
\hline & 1967 & Grubb \& Grathwohl, 1967 & $\begin{array}{l}\text { The psychic or symbolic value of goods purchased in the } \\
\text { marketplace }\end{array}$ \\
\hline \multirow{4}{*}{$1970 \mathrm{~s}$} & 1973 & Pohlman \& Mudd, 1973 & Product image is value for its utility as a prestige symbol \\
\hline & & Levy \& Glick, 1973 & $\begin{array}{l}\text { The concept of brand image aptly sums up the idea that } \\
\text { consumers buy brands not only for their physical } \\
\text { attributes and functions, but also because of the } \\
\text { meanings connected with the brands }\end{array}$ \\
\hline & 1978 & Levy, 1978 & $\begin{array}{l}\text { A mixture of the physical reality of the product and the } \\
\text { beliefs, attitudes and feelings that have come to the } \\
\text { attached to it meaning as being learned or stimulated by } \\
\text { the component experience that people have with the } \\
\text { product }\end{array}$ \\
\hline & 1979 & $\begin{array}{l}\text { Bettinger, Dawson, \& } \\
\text { Wales, } 1979\end{array}$ & $\begin{array}{l}\text { (BP) Products have personality images, an "adult" image } \\
\text { and a "child" image of the product-age image }\end{array}$ \\
\hline $1980 \mathrm{~s}$ & 1983 & Swartz, 1983 & $\begin{array}{l}\text { In symbolic consumer, interest lies in investigating the } \\
\text { role of products as "messages" - "the messages } \\
\text { communicated by products" }\end{array}$ \\
\hline
\end{tabular}


1984 Reynolds \& Gutman, 1984

Hendon \& Williams, 1985

1985

Sirgy, 1985

Dichter, 1985

Friedmann \& Lessig, 1987

1987

Durgee \& Stuart, 1987

1988 Noth, 1988

1990 Dobni \& Zinkhan, 1990

1991 Aaker, 1991

$1990 \mathrm{~s}$

1992 Biel, 1992

Keller, 1993

1993

1996 Aaker, 1996

2001

Vazquez, del Rio, \&

Iglesias, 2001

2000

Ross, James, \& Vargas, 2006

2008 Shank, 2008
Product imagery- stored meanings that an individual has in memory, personal and social meanings

The set of meanings and associations that serve to differentiate a product or service from its competition

Brand personality or brand character involves nothing more than describing a product as if it were a human being -"brand character"

Products are assumed to have personality image, just as people do -"personality image"

Brand image is the configuration of the whole field of the object, the advertising, and more important, the customer's disposition and the attitudinal screen through which he observes.

A mental position, understanding or evaluation of the product that develops in a nonrandom way form interaction between perceiver and product stimulus "psychological meaning"

Each product or brand has a "meaning profile" which is defined as the complex of key meanings associated with the product or brand of what the product means symbolically in the eyes of consumers - "Brand meaning"

Brand image include technical matters, product characteristics, financial value or social suitability

Meaning that the consumers associate with the product based on \{experiences, impressions, perceptions\} of \{functional, emotional, symbol\} benefits of the brand

(BA) Anything in a consumer's memory linked to a specific brand (p.109)

A set of associations usually organized in some meaningful way

The associations linked to brand

Cluster of attributes and associations that consumer's connect to the brand name

Perceptions about a brand as reflected by the brand associations held in consumer memory (p.3)

(BA) The informational nodes linked to the brand node in memory and contain the meaning of the brand for consumers

(BI) A unique set of associations that the brand strategist aspires to create or maintain

How organization want to the brand to be perceived

Perceptions about a brand as reflected by the cluster of associations that consumers connect to the brand name in memory

Networks of knowledge elements stored in long-term memory, and the core of such a network is the brand name which is linked to a number of other knowledge elements and/or associations (p. 67)

(BA) The thoughts that come to mind immediately after the brand is recalled

The consumers' set of beliefs about a brand with, in turn, 
Keller, 2008

Arai, Ko, \& Kaplanidou, 2013

2014 Roy \& Banerjee, 2014

2014

Anselmsson, Bondesson, \& Johansson, 2014 shape attitudes

The personality of the brand

Consumer perceptions of any preferences for a brand, measured by the various types of brand associations held in memory (p. 636)

The consumer's perceptions about the brand as reflected by a set of brand associations held in consumer's memory (p. 384)

The perception of a brand that is being formed in the process of decoding brand identity facets (p. 2)

The associations and beliefs that the customer has regarding the brand (p. 4)

Note: Adapted and modified from 'In search of brand image: a foundation analysis.' (p.112), by Dobni, D. \& Zinkhan, G. M. (1990), Copyright 1990 by the Association for Consumer Research. BP= Brand personality, $\mathrm{BA}=$ Brand associations, $\mathrm{BI}=$ Brand image.

As shown in Table 2, numerous definitions of brand image have been proposed over the last six decades. Some scholars used the same terminology to refer to diverse conceptualizations of brand image, while others created phrases to refer to similar or identical concepts. In examining the chronological transition of brand image, the following three time categories emerge: 1950 s to 1970 s, 1980s, and 1990s to present.

\subsubsection{0s to $1970 \mathrm{~s}$}

From 1950 through the 1970s, brand image was defined as the sum of a customer's cognitive and affective perceptions along with a product's physical attributes (Garner \& Levy, 1955; Herzog, 1963; Levy, 1978; Newman, 1957; Pohlman \& Mudd, 1973). Physical functions formed the basis of brand image as well as further associations with the abstraction over goods. In this period, product image and brand image were not clearly distinguished and were used interchangeably. It is important to note that during this period, the term product was essentially interchangeable with the term good. The focus was on goods and did not include services. Subsequently, product image was substituted for most definitions of brand image (Pohlman \& Mudd, 1973). However, these concepts are entirely different in terms of the tangibility of their locus; a brand is an intangible asset that exists in the customer's mind while a product (or good) is a physical asset that exists in the customer's physical space. These concepts merge when product image becomes part of brand image. Some researchers used meanings (Levy, 1978; Levy \& Glick, 1973; Sommers, 1964), symbols (Grubb \& Grathwohl, 1967; Martineau, 1957; Pohlman \& Mudd, 1973), and associations such as beliefs, attitudes, and feelings to describe brand image. Although several terms were used to describe these concepts, they all denoted an abstract perception of brand image. For instance, the utilitarian images of the Nike Air Max series occupy Nike's brand images as revolutionary, innovative, and ingenious. The product images of Nike, "best of what's new," which were derived from combining a name, logo, and symbols of Air Max, were brand images in this time era.

\subsubsection{0s}

The symbolic concept of brand gained popularity throughout the 1980s (Dobni \& Zinkhan, 1990). A brand as a symbol appealed to many researchers and managers because they believed their products reflected the morals and self-imagery of their customers (Hendon \& Williams, 1985; Sirgy, 1985). During the 1980s, brand image was defined, measured, and researched within the framework of a symbolic concept. Researchers used messages (Swartz, 1983), meanings (Durgee \& Stuart, 1987; Reynolds \& Gutman, 1984), and associations to depict abstract perceptions of their customers' minds. For the period of the 1980s, it is necessary to note that the image processing was discussed from the perspective of the symbolic meaning of products (Friedmann \& Lessig, 1987). For example, the Marlboro Man as the ultimate American cowboy and masculine image helped establish Marlboro as the best-selling cigarette in the world. The image of Virginia Slims, on the other hand, was a more dainty and feminine cigarette for the female smoking populace - the symbolic images of users' influence on the entire images of the product and the brand in the era. A product (or good) image and brand image were soon to become separated.

\subsubsection{0s to Present}

From the beginning in the 1990s, brand image was portrayed as being separate from product image. The image of a 
service was now also considered to be a part of brand image. Aaker (1991) and Keller (1993), two notable authorities on branding, dominated the definitions of branding, including brand image. Aaker (1996, p. 68) employed the concept of brand identity, which refers to "a unique set of associations that the brand strategist aspires to create or maintain." In his description, brand identity is the image that the corporation wishes the customer to perceive. Brand image was represented on the sender's perspective. Even though he pointed out that brand image is one input along with patience, resources, or expertise which were thought to comprise brand identity, the definition itself tends to be similar and included in Keller's (1993) brand association notion (i.e., the sum of the customer's perceptions), which was most accepted in this period. Furthermore, his term leads to greater confusion for practitioners and researchers by using different terminology to describe part of the entire concept.

Keller (1993) initially defined brand image based on "associative network models of memory." This approach asserted the belief that customers' informational nodes were linked to brands in their memories. Keller (2001) conceptualized a consumer-based brand equity model consisting of six brand-building elements. The four elements (i.e., judgments, feelings, performance, and imagery) within the model purported to comprise a (new) definition of brand image. That is, brand image is formed by the four elements. His definition is, however, problematic because its components contain several limitations driven from the imperfections of the conceptualization.

\subsection{Limitations of the Traditional Concepualizations}

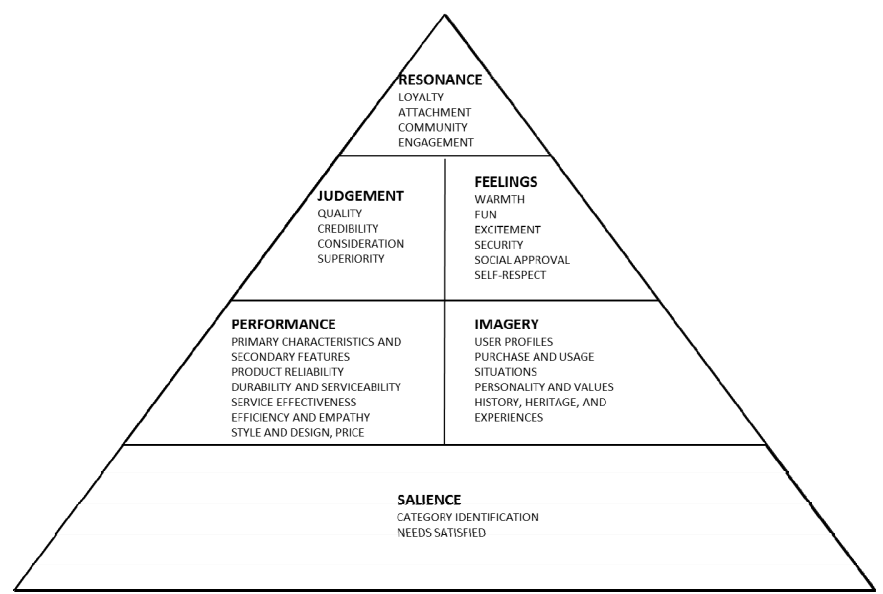

Figure 1. Sub-dimensions of brand-building elements (Keller, 2008)

It Keller's model presents a systematic process to build brand equity (see Figure 1). Four elements - performance, imagery, judgments, and feelings - form brand image based on Keller's definition. He classified and distinquish brand image into functional, symbolic, evaluative and emotional dimentions. However, there are several limitations with Keller's conceptualization despite its popularity. Three limitations were discussed in the following sections: (1) the overlap between parallel elements, (2) the overlap between upper and lower elements, and (3) the misinterpreted dimension of criteria for performance and imagery: Strength.

\subsubsection{Limitation 1: The Overlap between Parallel Elements}

To discriminate unique characteristics between parallel elements is difficult. That is, they are not clearly distinguishable; their meaning and features overlap each other. The problem lies (1) between performance and imagery elements and (2) between judgment and feelings elements. At a glance, the distinction between brand imagery and brand performance based on extrinsic and intrinsic properties of a product seems to make sense. However, the aesthetic categories Keller presents in Figure 1 for functionality, design, and style are more likely to belong to the imagery category because they are extrinsic attributes rather than functions or utilitarian purposes. One of the features of the "performance" element - design and style - conveys social needs. For example, suppose a consumer plans to purchase running shoes and compares Nike and Puma. In a general sense, Nike has a positive image regarding performance, whereas Puma has a good image regarding the design of its products rather than fuctionality. They both have a high level of quality, even presuming that one is slightly superior to the other. The consumer may be attracted by the design and style of the shoes and desire to represent his or her self-worth by purchasing a pair of Puma running shoes. If this is the case, the aesthetic heature can be considered brand imagery element. 
The same concern occurs between judgments and feelings elements. The features of judgments such as trustworthiness, likability and credibility are more likely to be feelings because they comprise customers' emotional reactions. The key scheme to distinguish these two elements will be to determine how personal emotions and opinions differ. Judgments can proceed through feelings, whereas feelings may include judgments. Presume that the consumer says, "I love Nike (rather than Puma)." Is this sentence an emotion or opinion? The answer for this is it can be both. It can be an opinion because he or she conveys his or her beliefs and attitudes toward the brand, whereas, at the same time, it can be considered as he or she expresses feeling of affection about the brand. Thus, it is difficult to differentiate between judgments and feelings.

The fundamental limitation of the conceptualization is that there is no clear-cut method to distinguish between parallel elements (or concepts). Although Keller presents four elements (see Figure 1) - performance, imagery, judgments, and feelings - in fact, it is not necessary to distinguish them. The categories of each element overlap one another; it is impossible to simply discriminate one element from the other.

\subsubsection{Limitation 2: The Overlap between Upper and Lower Elements}

The second limitation is that upper and lower elements - brand performance and judgments or brand imagery and feelings - occur neither hierarchically nor distinctively in the customer's mind, as Keller suggests in Figure 1. He proposes the elements (or concepts) are a sequence of series; thus, "judgments and feelings" elements can be established after a concrete creation of "performance and imagery" elements. Take the white paper cup with a green circle on it. Many consumers will associate it with Starbucks. When thinking of Starbucks, it is easy to describe its brand images as earthy green, a friendly and welcoming atmosphere, the warm coffee aroma, comfortable seating, an intense flavor, and a cool place to read, work, and relax. If the images are classified according to Keller's elements of brand image compulsively, intense flavor and earthy green are likely to be categorized as performance due to the fact that they are an intrinsic property and the design of the product, respectively. Comfortable seating and the warm coffee aroma may be imagery because they are more likely to be associated with usage situations and experiences - the extrinsic properties of a product. A cool place to read, work, and relax that neither an office nor a house can provide is likely to be a judgment element because it is the customer's personal opinions of the brand. A friendly and welcoming atmosphere is a "feelings" element because this is the emotional reaction that customers experience for a brand. According to Keller's four elements structure, the "judgments and feelings" elements (e.g., a friendly and welcoming atmosphere and a cool place) should emerge after establishing "brand performance and imagery" elements (e.g., comfortable seating and an intense flavor). However, multiple questions arise regarding the following: if brand image decomposes into four different elements as Keller proposed, do people imagine those images in order? How is it that those images come first, and then other images follow in the mind? Does this process make sense? The answers to the questions are perhaps impossible to know because the process of brand image cannot be preceded hierarchically. In other words, images from upper elements are not resultant from lower elements. In fact, all the images in a customer's mind cannot be distinctively classified into the elements and have a sequences of a series as Keller proposes in his pyramid. For example, the highly interrelated elements between lower (i.e., performance) and upper elements (i.e., judgments) can be specifically examined. Keller indicates that quality is a part of the judgments element. However, it is obvious that quality is the main feature when a customer thinks about functionality and utilitarian purposes, which is classified as "performance." Functionality heavily depends on the quality of a product because the quality is the basis of the intrinsic attributes. The customer already acknowledges the functions of $3 \mathrm{M}$ sticky notes if he or she has an image derived from the quality. Therefore, the distinction is neither possible nor necessary between the hierarchal elements in the pyramid.

\subsubsection{Limitation 3: A Misinterpreted Dimension of the Criteria for "Performance and Imagery" Elements: Strength}

According to Keller (2001), there are three dimensions of criteria for "performance and imagery" elements: (1) strength, (2) favorability, and (3) uniqueness. Strength is described as "how strongly the brand is identified with a brand association" (p. 18), and favorability is the degree of brand worthiness to customers. Uniqueness is aligned with the distinctiveness of the brand. By the definition of the three dimensions, strength is more likely to relate to the degree of brand awareness (termed "salience" by Keller) because it deals with recognition (or identification) among brands. In order to identify a brand, it is necessary to recall that brand. It is reasonable to say the strength of recall exists among brands. However, it is questionable to ascertain that there is strength among images of a brand. Images within the brand can be listed; however, the top list among images does not necessarily mean the images are stronger than the bottom list images. The order of images is simply one of images. For example, if the researcher asks, "Which brand has a strong brand image among coffee franchises category?" then a consumer may answer as "Starbucks, Gloria Jean's Coffee, Dunkin' Donuts, and McCafe." There is an obvious degree of strength (or 
magnitude) and an order among those four brands. Starbucks has a stronger brand image than Dunkin' Donuts or McCafe. However, if the researcher asks, "Which image has a stronger brand image when you think of Starbucks?" The consumer can respond as "earthy green," "friendly and welcoming atmosphere," "cool place," "comfortable seating," and "warm coffee aroma." However, the order does not necessarily imply the strength or weakness among images. That is, although he or she imagines those images in order, it does not indicate one image is stronger or weaker than others. For instance, is an earthy green image weaker than a friendly and welcoming atmosphere? The question and distinction among images within the brand seem meaningless. If the consumer imagines such images, those images have equivalent weight unless he or she compares the images that are barely related to the brand. Thus, the criterion, strength, which the researcher presents, should be the criterion of magnitude toward brand awareness, not brand image. It is almost impossible to judge the strength among images within the brand.

\subsubsection{Summary}

Despite that Keller proposed and developed the branding studies including brand-related conceptualizations, there were few drawbacks that limit the later scholars and practitioners' understanding of brand image. First, Keller failed to capture the concept, brand image, broadly. Consumers are not likely to perceive any lucid distinctions between the elements as he proposed. Second, a sequential series cannot exist among the elements when consumers think of, feel, and evaluate a certain brand. Last, the fundamental limitation of Keller's brand image definition and conceptualization is that there is no clear-cut distinction between parallel and hierarchical elements as in the conceptualization. The specified categories of each block that Keller indicates heavily overlap one another. The definition of brand image should be interpreted to equate to a combination of the four elements (i.e., judgments, feelings, performance, and imagery) within the model. The problem lies in the definition, as the framework is the result of a poor definition. Hence, it is important to redefine "brand image." As such, the researchers drew a conclusion based on the previous brand image definitions. Brand image should not be simply a sum of associations, as many previous researchers suggested; also, it should not be separable to distinguish between cognitive, affective, and evaluative components in the brand image. The definition should be integrated into three perspectives (i.e., cognition, affection, and evaluation) and should not be distinguished into several elements. The image consumers have is the outcome that went through a combination of a cognitive, affective, and evaluative process. Therefore, based on the previous definitions and conceptualizations, the researchers proposed a unified definition of brand image as "the sum of a customer's perceptions about a brand generated by the synthetic interaction of the cognitive, affective, and evaluative processes in a customer's mind."

\section{Discussion}

After examining brand image definitions and recent research (Aaker, 1991; 1996; Biel, 1992; Dobni \& Zinkhan, 1990; Herzog, 1963; Keller, 1993; 2001; Levy \& Glick, 1973; Martineau, 1957; Newman, 1957; North, 1988; Pohlman \& Mudd, 1973; Reynolds \& Gutman, 1984; Sirgy, 1985; Swartz, 1983), it is clear that the concept of brand image from various researchers was poorly addressed and interpreted. As shown in Table 1, the classification of terms is vague and often does not make sense. The chronological transition of definitions in Table 2 also demonstrates similar issues. The limitations of Keller's (2001) conceptualization indicate that the features of elements (i.e., performance and imagery, judgments and feelings) overlap with one another and do not actually occur in hierarchical order as Keller proposes. The most crucial problem is the image is not considered in a combination of a process of cognitive, affective, and evaluation toward a brand. When the brand IRONMAN triathlon event is cued, the image of strong athletes (i.e., the simple association of a brand) as positive image (i.e., the result of evaluation of a brand) comes up. The entire picture with several images is the result of a sum of associations that have already been synthesized and evaluated in the customer's mind. The intense flavor of Starbucks coffee does not exist without customers' evaluation of it (e.g., positive or favorable image). Whenever they think of the flavor, it is the outcome of evaluation that has been created through customers' synthesis. It is irrational that customers have images without processing any evaluations. All brand images that the customer has are the results of his/her brand associations through synthesis toward a brand. That is, the images are not simply outcomes of a sum of association(s) and should not be interchangeably used with associations as synonym. Brand image is a combination of the process of cognition, affection, and evaluation. These three cannot be separately proceeded. Therefore, there is a need to integrate definition that captures previous definitions, terminology, and similar concepts. In this purpose, the researchers suggest a revised and unified definition to capture and reinterpret all the concepts discussed in the literature review and the definition as follows:

The sum of a customer's perceptions about a brand generated by the interaction of the cognitive, affective, and evaluative processes in a customer's mind. 
The consensus definition of brand image will offer several benefits for researchers and practitioners. First, the unified definition will provide effectiveness for researchers and practitioners to indicate and address the concept of brand image. Due to the ill-defined concepts, multiple terminology was used to specify the identical concept, or the different concepts were interchangeably used under the term brand image. If the definition is well-defined and well-represented, there will be less confusion among practitioners and researchers. If the concept is defined in a consistent way, the usages and applications of brand image will provide more effective tools to characterize and measure the construct.

Because of discordant definitions, there has been multiple means to measure brand image by various scholars. The multiple definitions and interpretations have caused the concept of brand image to become understood in a way that is far from the intent and meaning originally ascribed. A universally concord definition will offer scholars and practitioners to represent and reinterpret the identical concept with unified terminology and meaning.

Second, with an accord term, planning and implementing the marketing strategies will be easier and more efficient. Setting a target population and positioning the brand in the desirable directions and locations in the consumers' minds are one of the important marketing projects for firms. In order to clearly convey the company's goal and to position their brands, appropriate brand images are required. However, if there are no accord definitions and interpretation of brand image, pertinent positioning strategies will be impossible. This is because positioning is the strategy that portrays exclusive brand images to potential consumers to take an advantage over other competitors in the battle of customers' minds. Introducing, elaborating, and fortifying brand images based on well-defined construct forms are the basis for better strategic decisions about how to target the market and position the brands. The branding management begins with brand image creation and reinforcement.

Third, as Aaker and Biel (1993) insisted, brand image is a critical component of brand equity. The ultimate goal of marketing is to establish a high level of brand equity so that the outcome, strong brand equity, makes selling superfluous and the brand itself desirable. Marketers attempt to create positive and favorable brand images because such images serve a role to generate positive and favorable attitudes toward the brand. The positive and favorable attitudes increase the likelihood of a high level of brand equity. The establishment of well-defined and well-addressed brand image will enable researchers and practitioners to build concrete brand equity, which is the ultimate goal of marketing.

The lack of consensus regarding the definition of the term, brand image, restricts the efficient management and positioning of a brand. The imprecise definitions also limit the implement of the concept and cannot well serve an essential role between brand image and brand equity. Based on the universally unanimous definition and interpretation, the measure of brand image also will be possible. Therefore, the researcher's objective - to reinterpret the concept of brand image and to offer a clear definition of the term-will benefit further research and marketing not limited brand image but also brand equity and positioning research. As brand image is the central element to establish a higher level of brand equity and distinctive brand positioning, the process of readdressing the concept was necessary.

\section{References}

Aaker, D.A. (1991). Managing brand equity. The Free Press: New York, NY.

Aaker, D. A. (1996). Building strong brands. New York: Free Press.

Aaker, D. A., \& Biel, A. (1993). Brand equity \& advertising: Advertising's role in building strong brands. Hilldale: Lawrence Erlbaum Associates.

Aaker, J. (1997). Dimensions of brand personality. Journal of Marketing Research, 34(3), 347-356. http://dx.doi.org/10.2307/3151897

Ambler, T. (2003). Marketing and the bottom line: The marketing metrics that will pump up cash flow. Pearson Education.

Anselmsson, J., Bondesson, N. V., \& Johansson, U. (2014). Brand image and customers' willingness to pay a price premium for food brands. Journal of Product \& Brand Management, 23(2), 3-37.

Arai, A., Ko, Y. J., \& Kaplanidou, K. (2013). Athlete brand image: scale development and model test. European Sport Management Quarterly, 13(4), 383-403. http://dx.doi.org/10.1080/16184742.2013.811609

Bettinger, C. O., Dawson, L. E. Jr, \& Wales, H. (1979). The impact of free sample advertising. Journal of Advertising Research, 19(3), 35-40. 
Biel, A. L. (1992). How brand image drives brand equity. Journal of Advertising Research, 32(6), 6-12.

Del Rio, A. B., Vazquez, R., \& Iglesias, V. (2001). The effects of brand associations on consumer response. Journal of Consumer Marketing, 18(5), 410-425. http://dx.doi.org/10.1108/07363760110398808

Dichter, E. (1985). What's in an image? Journal of Consumer Marketing, 2(1), 75-81. http://dx.doi.org/10.1108/eb038824

Dobni, D., \& Zinkhan, G. M. (1990). In search of brand image: a foundation analysis. Advances in Consumer Research, $17,110-119$.

Drucker, P. F., \& Maciariello, J. A. (2008). Management (Rev. Ed.). New York: Harper Collins.

Durgee, J. F., \& Stuart, R. W. (1987). Advertising symbols and brand names: That best represent key product meanings. The Journal of Consumer Marketing, 4(3), 15-24. http://dx.doi.org/10.1108/eb008200

Friedmann, R., \& Lessig, V. P. (1987). Psychological meaning of products and product positioning. Journal of Product Innovation Management, 4, 265-73. http://dx.doi.org/10.1016/0737-6782(87)90030-0

Gardner, B. B., \& Levy, S. J. (1955). The product and the brand. Harvard Business Review, 33(2), 33-39.

Grubb, E. L., \& Grathwohl, H. L. (1967). Consumer self-concept, symbolism and market behavior: A theoretical approach. The Journal of Marketing, 22-27. http://dx.doi.org/10.2307/1249461

Hendon, D. W., \& Williams, E. L. (1985). Winning the battle for your customer. Journal of Consumer Marketing, 2(4), 65-75. http://dx.doi.org/10.1108/eb008147

Herzog, H. (1963). Behavioral science concepts for analyzing the consumer. Marketing and the Behavioral Sciences, 76-86.

Ives, N. (2005, May 5). Nike decides not to do business with Sears. The New York Times. Retrieved from http://www.nytimes.com/2005/05/05/business/media/05adco.html?_r=0

Keller, K. L. (1993). Conceptualizing, measuring, and managing customer-based brand equity. Journal of Marketing, 57, 1-22. http://dx.doi.org/10.2307/1252054

Keller, K. L. (2001, July/August). Building customer-based brand equity. Marketing Management, 15-19.

Keller, K. L. (2008). Strategic brand management. Upper Saddle River: Pearson Prentice Hall.

Levy, S. J. (1978). Marketplace behavior-its meaning for management. Amacom.

Levy, S. J. (1999). Imagery and symbolism. Brands, Consumers, Symbols and Research: Sidney J Levy on Marketing, 233.

Martineau, P. (1957). Motivation in advertising: Motives that make people buy. New York: McGraw-Hill.

Newman, J. W. (1957, November-December). New Insight, New Progress, For Marketing. Harvard Business Review, 95-102.

Nöth, W. (1988). The language of commodities Groundwork for a semiotics of consumer goods. International Journal of Research in Marketing, 4(3), 173-186. http://dx.doi.org/10.1016/S0167-8116(88)80003-X

Park, C. W., Jaworski, B. J., \& Maclnnis, D. J. (1986). Strategic brand concept-image management. The Journal of Marketing, 50(4), 135-145. http://dx.doi.org/10.2307/1251291

Pohlman, A., \& Mudd, S. (1973). Market image as a function of group and product type: A quantitative approach. Journal of Applied Psychology, 57(2), 167-71. http://dx.doi.org/10.1037/h0037043

Reynolds, T. J., \& Gutman, J. (1984, February-March). Advertising is image management. Journal of Advertising Research, 24, 27-38.

Ries, A., \& Trout, J. (2000). Positioning: The battle for your mind. New York: McGraw-Hill.

Riezebos, R., Riezebos, H. J., Kist, B., \& Kootstra, G. (2003). Brand management: A theoretical and practical approach. Pearson Education.

Ross, S. D., James, J. D., \& Vargas, P. (2006). Development of a scale to measure team brand associations in professional sport. Journal of Sport Management, 20, 260-279.

Roy, D., \& Banerjee, S. (2014). Identification and measurement of brand identity: A quantitative approach. Journal of Product \& Brand Management, 23(3), 6-36. 
Shank, M. D. (2008). Sports marketing: A strategic perspective. Upper Saddle River: Pearson Prentice Hall.

Shankar, V., Azar, P., \& Fuller, M. (2008). Practice Prize Paper-BRAND* EQT: A Multicategory Brand Equity Model and Its Application at Allstate. Marketing Science, 27, 567-584.http://dx.doi.org/10.1287/mksc.1070.0320

Simon, C. J., \& Sullivan, M. V. (1993). The measurement of determinants of brand equity: A financial approach. Marketing Science, 12, 28-52. http://dx.doi.org/10.1287/mksc.12.1.28

Sirgy, M. J. (1985). Using self-congruity and ideal congruity to predict purchase motivation. Journal of Business Research, 13, 195-206. http://dx.doi.org/10.1016/0148-2963(85)90026-8

Sommers, M. S. (1964). Product symbolism and the perception of social strata. In Proceedings of the American Marketing Association, 22, 200-216.

Swartz, T. A. (1983). Brand symbols and message differentiation. Journal of Advertising Research, 23(5), 59-64.

Vázquez, R. K., del Rio, A. B., \& Iglesias, V. (2002). Consumer-based brand equity: Development and validation of a measurement instrument. Journal of Marketing Management, 18, 27-48. http://dx.doi.org/10.1362/0267257022775882

Washburn, J. H., \& Plank, R.E. (2001). Measuring brand equity: An evaluation of a consumer-based brand equity scale. Journal of Marketing Theory and Practice, 10, 46-62.

Yoo, B., Donthu, N., \& Lee, S. (2000). An examination of selected marketing mix elements and brand equity. Journal of the Academy of Marketing Science, 28, 195-211. http://dx.doi.org/10.1177/0092070300282002 